\title{
Analisis Faktor Kapasitas Pembangkit Listrik Hibrida PLTB dengan PLTD di Pulau Terpencil: Studi Kasus Elat Pulau Serau Maluku
}

\author{
FRANSISCO DANANG WIJAYA ${ }^{1}$, I WAYAN ADIYASA ${ }^{2}$, EKRAR WINATA ${ }^{3}$ \\ ${ }^{1}$ 1Departemen Teknik Elektro dan Teknologi Informasi Fakultas Teknik UGM \\ 2Jurusan Pendidikan Teknik Otomotif Fakultas Teknik UNY \\ 3Pusat Studi Energi UGM \\ Email:danangwijaya@ugm.ac.id
}

Received 18 Maret 2021| Revised 9 April 2021| Accepted 29 April 2021

\begin{abstract}
ABSTRAK
Rasio elektrifikasi di Indonesia belum mencapai 100\%, penyebabnya antara lain masalah lokasi di daerah terpencil atau kepulauan dan mahalnya biaya operasi PLTD. Salah satu solusi adalah membangkitkan listrik berbasis energi terbarukan setempat. Tahap awal pemanfaatan energi terbarukan perlu dihitung faktor kapasitas (CF). Tujuan penelitian ini menganalisis CF untuk PLTB dengan metode perhitungan analitik berbasis potensi energi angin, spesifikasi teknologi PLTB dan $P L T D$, profil beban dan energi listrik yang dapat diproduksi untuk pengembangan sistem hibrida dengan mengambil kasus di Elat Pulau Serau Maluku. Hasil perhitungan CF untuk 5 teknologi PLTB yang berbeda dengan variasi ketinggian di Elat telah diverifikasi dengan simulasi menggunakan perangkat lunak HOMER dengan nilai rerata galat -0,030. Semakin tinggi PLTB, nilai CF semakin besar dengan konstanta 0,0030.
\end{abstract}

Kata kunci: elektrifikasi, faktor kapasitas, PLTB, PLTD, sistem hibrida

\begin{abstract}
The electrification ratio in Indonesia has not reached 100\%, the causes include problems with the location in remote areas or islands and the high operating costs of diesel power plant (DPP). One solution is to generate electricity based on local renewable energy. The initial stage of utilizing renewable energy needs to calculate the capacity factor (CF). The purpose of this research is to analyze CF for wind turbine generator (WTG) with analytical calculation methods based on wind energy potential, technology specifications of WTG and DPP, load profiles and electrical energy that can be produced for hybrid system development by taking the case in Elat Serau Island, Maluku. The results of CF calculations for 5 different WTG technologies with altitude variations in Elat have been verified by simulation using HOMER software with a mean error value of -0.030 . The higher the WTG, the greater the CF value with a constant of 0.0030 .
\end{abstract}

Keywords: electrification, capacity factor, diesel power plant, wind turbine generator, hybrid system 
Analisis Faktor Kapasitas Pembangkit Listrik Hibrida PLTB dengan PLTD di Pulau Terpencil: Studi Kasus

Elat Pulau Serau Maluku

\section{PENDAHULUAN}

Sampai dengan saat ini rasio elektrifikasi di Indonesia masih belum mencapai $100 \%$. Data rasio elektrifikasi dari Direktorat Jenderal Ketenagalistrikan Kementerian Energi dan Sumber Daya Mineral (ESDM) per Juni 2020 sudah naik menjadi 99,09\% dari 98,81\% di Juni 2019 (Kementerian Energi Dan Sumber Daya Mineral Republik Indonesia, 2019). Hal ini berarti bahwa masih ada 0,91\% dari jumlah penduduk Indonesia yang berdasarkan data Worldometers per 1 Oktober 2020 jumlah penduduk Indonesia adalah sebanyak 273.523.615 jiwa atau sekitar 2.489.065 jiwa yang masih belum dapat menikmati energi listrik (Worldometer, 2020). Padahal energi adalah prasyarat untuk kegiatan ekonomi dan sosial untuk pembangunan manusia serta untuk penyediaan air, perawatan kesehatan, pendidikan, dan kegiatan rekreasi. Peningkatan kesejahteraan penduduk salah satu faktornya dapat dicapai bila akses ke energi, dalam hal ini energi listrik, yang terjangkau dan andal tersedia dalam jumlah cukup (Plugia, dkk, 2017). Permasalahan yang menyebabkan masih sulitnya pencapaian $100 \%$ rasio elektrifikasi ini diantaranya karena faktor geografis yaitu lokasi yang sulit terjangkau, misal di daerah pegunungan yang jaraknya jauh dari infrastruktur seperti akses jalan atau di pulau terpencil. Selain faktor geografis, faktor yang menjadi penghambat adalah tersedianya teknologi yang andal dengan harga yang dapat terjangkau oleh masyarakat.

Ada beberapa metode yang telah dikembangkan untuk meningkatkan rasio elektrifikasi antara lain dengan pengembangan jaringan listrik yang sudah ada, pembangunan mini-grid (jaringan mini) yang terisolasi, dan sistem pico-grid (Subhes, 2016). Pengembangan jaringan listrik yang sudah ada dilakukan untuk lokasi yang dekat dengan jaringan listrik sehingga pengembangan jaringan listriknya tidak membutuhkan biaya yang mahal. Jaringan mini melibatkan pembangkit tenaga listrik skala kecil (10 kW hingga $10 \mathrm{MW}$ ) yang melayani jumlah terbatas konsumen melalui jaringan distribusi yang dapat beroperasi secara isolasi dari jaringan transmisi listrik nasional. Sedangkan sistem pico-grid adalah sistem yang berdiri sendiri (stand alone) diantaranya solar home system (SHS) dan sistem pico-photovoltaic (Sambodo, 2015). Pemerintah Indonesia telah berusaha untuk menerapkan ketiga metode di atas baik melalui Direktorat ESDM, PT. PLN dan swasta. Pada tahun 2019 pemerintah dengan perusahaan Jerman telah membangun sistem mini-grid dengan pembangkit listrik berbasis surya di berbagai lokasi di Indonesia sebagai upaya untuk meningkatkan rasio elektrifikasi (EBTKE, 2019). Program SHS juga telah diluncurkan dengan menggunakan lampu SHS yang dikhususkan untuk memenuhi kebutuhan penerangan di malam hari. Sistem ini menggunakan sel surya sebagai sumber energi listrik yang disimpan di baterai kapasitas kecil untuk mencatu lampu LED. Namun sistem ini banyak mengalami kegagalan pada komponen baterai yang mempunyai umur lebih rendah (Andrea, 2019).

Penelitian ini bertujuan untuk mengembangkan alternatif sistem kelistrikan mandiri jaringan mini hibrida dengan berbasis potensi energi terbarukan yang ada di lokasi setempat. Studi kasus dilakukan di lokasi hibridisasi yaitu Elat Pulau Selaru, Kei Besar, Kabupaten Maluku Tenggara, Maluku dengan koordinat lokasi -5.6516994,132.9821247. Peta lokasi ditunjukkan pada Gambar 1 bersumber dari Google Map. Hibridisasi pembangkit dilakukan untuk mengurangi ketergantungan sumber energi fosil pada Pembangkit Listrik Tenaga Diesel (PLTD) yang berbahan bakar minyak solar yang harganya relatif mahal, pengiriman bahan bakarnya sering terlambat dan mengakibatkan polusi udara sebagai efek karbon (PwC global power \& utilities, 2016). Oleh karenanya dikembangkan PLTB dengan memanfaatkan potensi energi angin. Diharapkan dengan pembangkit hibrida ini, keandalan pasokan bisa lebih baik sehingga rasio elektrifikasi pada Provinsi Maluku dapat ditingkatkan. Tahapan penulisan dalam artikel ini dimulai dengan latar belakang, dilanjutkan dengan metodologi penelitian, lalu hasil dan pembahasan serta ditutup dengan kesimpulan. 


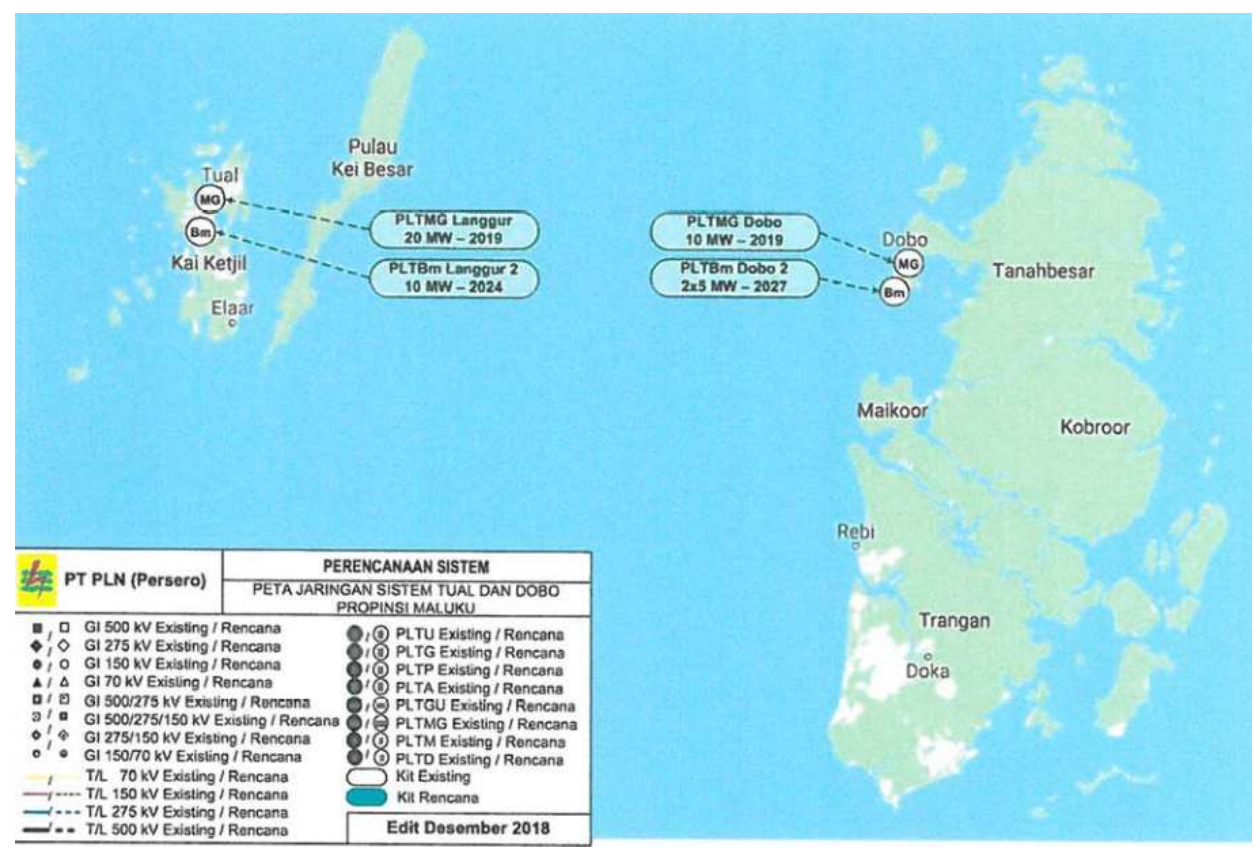

Gambar 1. Peta Lokasi Elat di Pulau Selaru Kabupaten Maluku Tenggara (Direktorat Jenderal Ketenagalistrikan, 2019)

\section{METODE PENGEMBANGAN SISTEM HIBRIDA PLTD - PLTB}

\subsection{Metodologi}

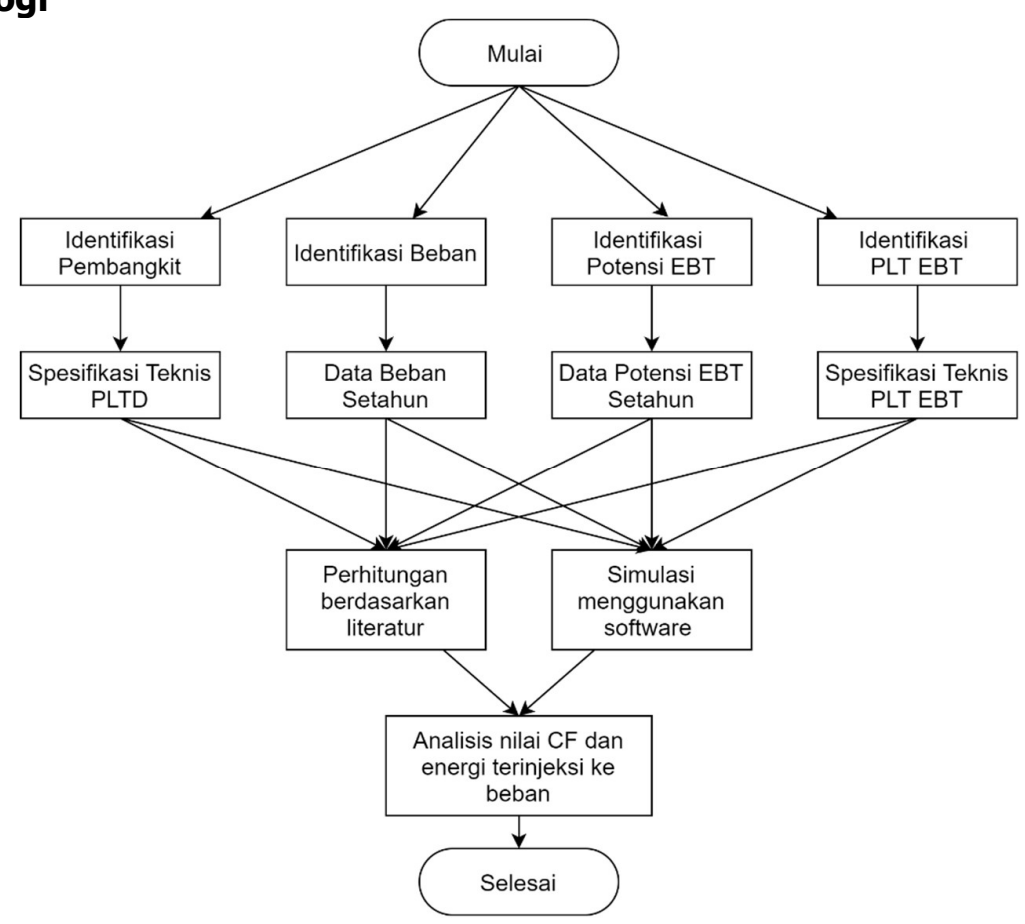

Gambar 2. Metodologi Analisis Faktor Kapasitas Pembangkit Listrik Hibrida PLTB dengan PLTD di Pulau Terpencil: Studi Kasus Elat Pulau Serau Maluku 
Gambar 2 menunjukkan metodologi hibridisasi sistem kelistrikan di Elat dengan mempertimbangkan pembangkit PLTD dengan PLTB sebagai pilihan. Dalam studi literatur, beberapa kajian baik jurnal maupun prosiding digunakan sebagai sumber dalam mengidentifikasi parameter, formulasi untuk melakukan perhitungan, hingga menentukan hasil akhir dari kajian. Beberapa parameter yang menentukan hasil kajian seperti data hasil identifikasi pembangkit listrik, identifikasi beban, identifikasi potensi energi baru terbarukan, dan identifikasi pembangkit listrik tenaga energi baru terbarukan (PLT EBT) digunakan sebagai masukan dalam formulasi perhitungan.

Untuk mencari besar potensi energi listrik yang dapat dihasilkan oleh PLTB, diperlukan perhitungan yang valid dengan formulasi diperoleh dari studi literatur. Spesifikasi PLTD dan PLTB yang akan digunakan ditetapkan sebagai dasar perhitungan berbasis data pabrikan. Selanjutnya dilakukan perhitungan dalam menentukan nilai daya listrik yang dapat dihasilkan selama satu tahun dan daya beban yang akan dicatu selama satu tahun. Kajian kelistrikan menggunakan dua metode, yaitu perhitungan berdasarkan studi literatur berbasis model matematis yang dikembangkan dan dengan menggunakan perangkat lunak HOMER. Hasil perhitungan diharapkan dapat menghasilkan besarnya nilai Capacity Factor (CF) dari pembangkit dan energi yang dapat digunakan untuk melayani beban.

\subsection{Identifikasi Parameter}

\subsubsection{Identifikasi PLTD Eksisting}

Untuk memulai pengembangan sistem mini-grid dengan pembangkit hibrida PLTD dengan PLTB, maka dibutuhkan data PLTD eksisting yang sudah ada, kondisi dan pola operasinya.

Berdasarkan data yang diperoleh, sistem listrik Elat memiliki 5 PLTD. Data identifikasi PLTD tersebut dapat dilihat pada Tabel 1. Semua PLTD aktif dengan total daya sebesar $1.200 \mathrm{~kW}$. Sedangkan energi listrik yang diproduksi oleh PLTD selama satu hari adalah sebesar 1.875 kWh dengan rerata CF sebesar 17,15 , sehingga profil beban di Elat memiliki rerata sebesar $205,79 \mathrm{~kW} /$ hari. Nilai tersebut diperoleh dengan perhitungan pada Persamaan (1) :

$$
P_{\text {beban }}=P_{\text {rating }} \times \frac{C F}{100}
$$

dengan $P_{\text {beban }}$ adalah daya beban yang dicatu sistem, $P_{\text {rating }}$ adalah daya rating PLTD dan CF adalah nilai capacity factor.

Tabel 1. Kondisi PLTD Sistem Listrik Elat

\begin{tabular}{|l|l|l|l|}
\hline \multicolumn{1}{|c|}{ Pembangkit } & \multicolumn{1}{|c|}{ Prating (kW) } & \multicolumn{1}{|c|}{ Energi (kWh) } & \multicolumn{1}{c|}{ CF (\%) } \\
\hline PLTD 1 & 250 & 223.320 & 10,20 \\
\hline PLTD 2 & 250 & 1.044 .612 & 47,70 \\
\hline PLTD 3 & 120 & 25.390 & 2,42 \\
\hline PLTD 4 & 500 & 346.650 & 7,91 \\
\hline PLTD 5 & 100 & 4.735 & 0,54 \\
\hline PLTD 6 & 500 & 1.249 .052 & 28,51 \\
\hline Total & $\mathbf{1 . 7 2 0}$ & $\mathbf{2 . 8 9 3 . 7 5 9}$ & \\
\hline
\end{tabular}

\subsubsection{Identifikasi Karakteristik Beban}

Identifikasi beban didasari dengan perhitungan daya yang dikonsumsi, $P_{\text {Beban }}$ yang diminta dalam waktu 24 jam. Gambar 3 menunjukkan grafik profil beban di Elat Maluku selama 24 jam. Terlihat bahwa rerata daya beban $P_{\text {Beban }} 205,79 \mathrm{~kW}$, dengan total energi $4.939,06$ 
kWh/hari. Pada jam 01:00 hingga 05:00, konsumsi daya cukup rendah. Di saat orang mulai beraktivitas pukul 06:00 hingga 10:00 mengalami peningkatan beban. Pada pukul 11:00 sampai 16:00 beban konstan. Tetapi saat pukul 17:00 sampai 19:00 terjadi peningkatan hingga terjadi beban puncak yang berlangsung hingga pukul 22:00. Setelah pukul 22:00, terjadi penurunan beban secara bertahap hingga pukul 24:00.

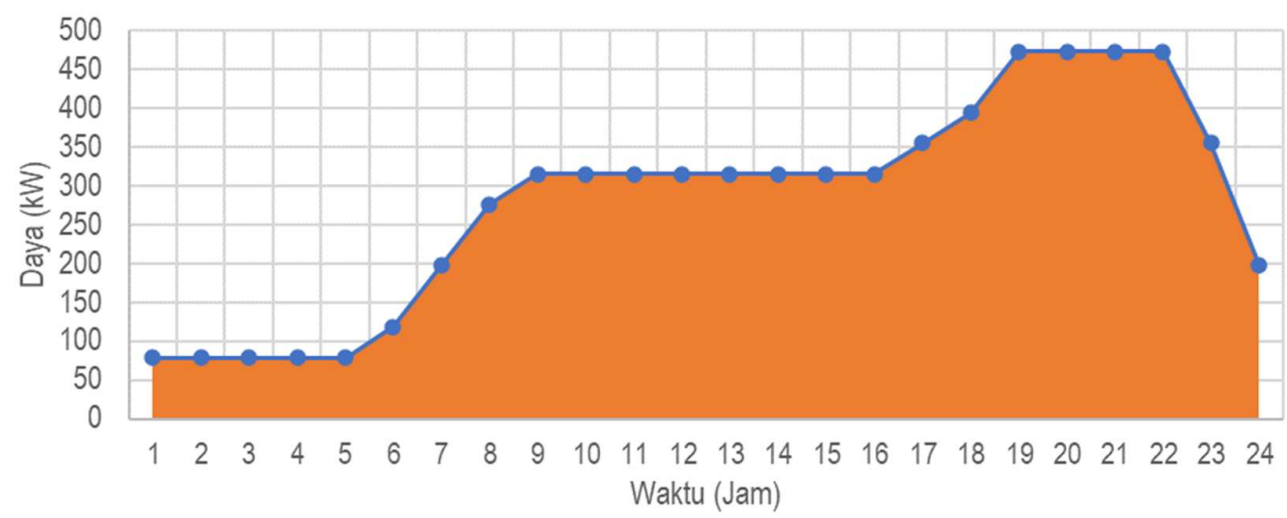

Gambar 3. Profil Beban di Elat

\subsubsection{Identifikasi Potensi Angin}

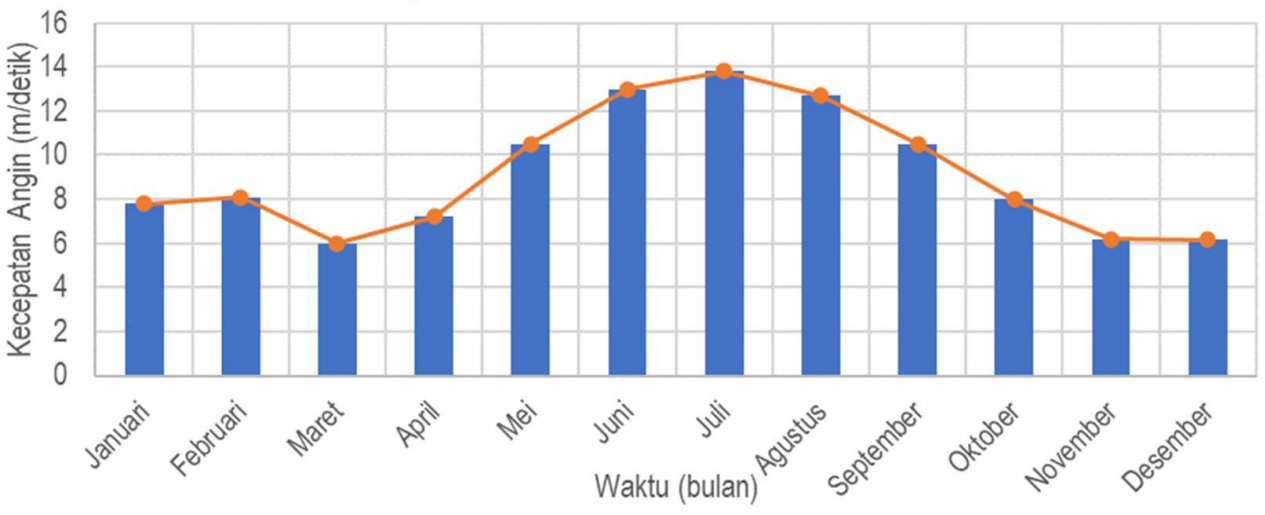

Gambar 4. Kecepatan Angin Rerata Setiap Bulan Selama Satu Tahun di Elat

Gambar 4 menunjukkan grafik potensi kecepatan angin rerata setiap bulan dalam satu tahun dari sumber data satelit NASA. Pada saat bulan Januari, kecepatan reratanya sebesar $7,8 \mathrm{~m} /$ detik. Saat memasuki bulan Februari, kecepatan angin naik menjadi 8,1m/detik. Pada bulan Maret, kecepatan angin menjadi $6 \mathrm{~m} /$ detik. Kecepatan angin tersebut merupakan rerata kecepatan angin paling rendah selama setahun. Sedangkan pada bulan Mei, Juni, Juli, Agustus, hingga September, rerata kecepatan angin mencapai nilai di atas $10 \mathrm{~m} /$ detik. Tentunya energi yang dihasilkan pada bulan ini sangat besar. Potensi energi yang besar dapat diproduksi pada bulan Mei hingga bulan September, sedangkan produksi energi sangat rendah berada pada bulan Maret, November, dan Desember.

\subsubsection{Perhitungan Faktor Kapasitas (CF) PLTB}

Gambar 5 adalah karakteristik pembangkitan energi pada PLTB yang terbagi ke dalam 4 daerah operasi (region). Region 1 menunjukkan PLTB tidak memproduksi energi listrik. Saat kecepatan sebesar $v_{c u t-i n}$ PLTB mulai untuk memproduksi energi listrik. Energi listrik yang 
dihasilkan pada awal wilayah Region 2 sangat rendah. Kecepatan angin yang meningkatdan melebihi $v_{\text {cut-in }}$ maka produksi energi listrik lebih besar. Saat kecepatan angin berada pada $v_{\text {rated, }}$ energi yang diproduksi PLTB mencapai daya puncak atau $P_{r}$. Energi sebesar $P_{r}$ diproduksi pada wilayah Region 3 (Al-Quraan \& Alrawashdeh, 2018) (Chang, dkk, 2014) (Gharibeh, dkk, 2019).

Saat kecepatan angin berada di nilai $v_{\text {cut-out, }}$ maka daya keluaran PLTB menjadi 0 atau tidak menghasilkan energi listrik. Jika kecepatan angin berada di wilayah Region 4, PLTB berhenti memproduksi energi untuk melindungi generator dari over speed yang dapat mengakibatkan kerusakan.

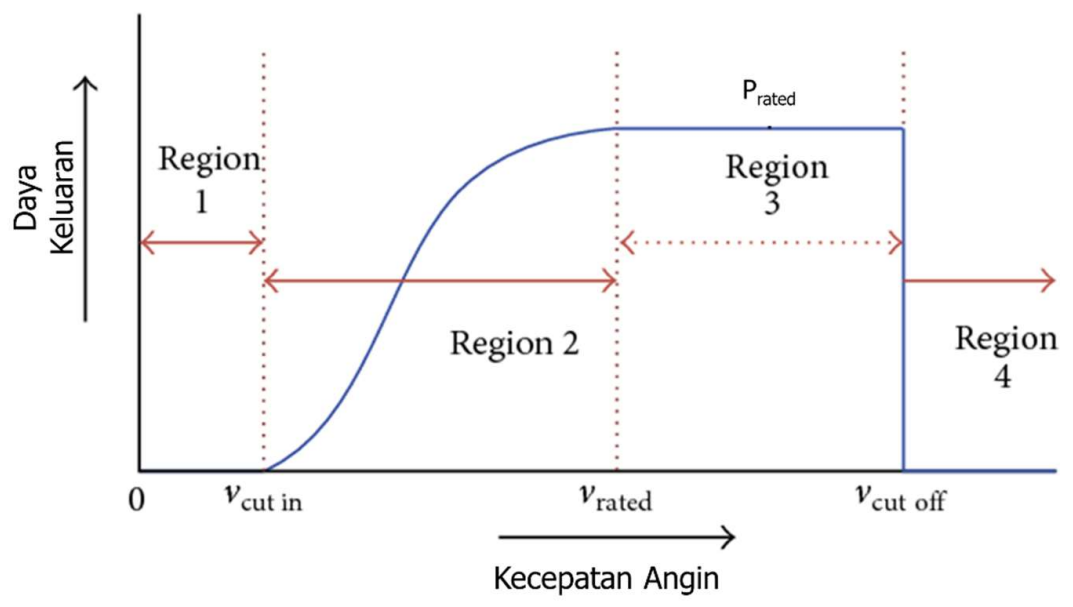

Gambar 5. Karakteristik Pembangkitan Daya Listrik pada PLTB

Persamaan (2) menunjukkan keluaran daya listrik dari PLTB $\left(P_{W T e}(v)\right)$ berdasarkan kecepatan angin (Bokde, 2018) (Diyoke, 2019). Nilai $P_{W T e}(v)$ merupakan perkalian daya keluaran PLTB $P_{r}$ dengan rasio kecepatan angin dari nilai 0 sampai dengan 1 . Nilai $P_{r}$ menyesuaikan daya maksimum PLTB yang digunakan (Al-Quraan \& Alrawashdeh, 2018) (Song dkk, 2019) (Walia \& Sandhu, 2019).

$$
P_{W T e}(v)=P_{r} \times\left\{\begin{array}{l}
0, \quad v<v_{\text {cut }-} \\
P_{f}, v_{\text {cut }-} \leq v \leq v_{\text {rated }} \\
1, v_{\text {rated }} \leq v \leq v_{\text {cut }- \text { out }}
\end{array}\right.
$$

Jika kecepatan angin $(v)$ lebih kecil dari $v_{c u t-i n}$, maka $P_{r}$ dikalikan dengan 0 . Sedangkan nilai $P_{f}$ bervariasi dari 0 sampai 1 yaitu jika $v$ lebih besar dari $v_{\text {cut-in }}$ dan lebih kecil dari $v_{\text {rated }}$. Nilai $P_{r}$ terkalikan 1 jika nilai $v$ lebih besar dari $v_{\text {rated }}$ dan lebih kecil dari $v_{\text {cut-out }}$.

Persamaan (3) menunjukkan perhitungan daya listrik yang dihasilkan oleh PLTB dengan $\rho$ merupakan kepadatan udara, $A$ area sapuan dari baling-baling rotor, $C p$ koefisien performa turbin, $\eta_{m}$ efisiensi mekanik, dan $\eta_{G}$ efisiensi generator (Diyoke, 2019).

$$
P_{W T e}(v)=\frac{1}{2} \rho A v^{3} C_{p} \eta_{m} \eta_{G}
$$

Pada perangkat lunak Hybrid Optimization of Multiple Energy Resources (HOMER), $P_{W T e}(v)$ dari suatu PLTB ditentukan berdasarkan tabel kurva daya (power curve). Nilai kurva daya berdasarkan kecepatan angin pada suatu PLTB sudah ditetapkan berdasarkan produk PLTB 
yang akan digunakan (Diyoke, 2019). Untuk mempermudah perhitungan energi yang dibangkitkan berdasarkan data kecepatan angin dan tabel kurva daya, maka digunakan Persamaan (4).

$$
P_{W T e}(t)=P_{P C}(v)
$$

Dengan $P_{W T e}(t)$ merupakan energi yang dihasilkan pada waktu tertentu, $P_{P C}(v)$ merupakan daya tabel kurva daya pada kecepatan angin tertentu. Jika sebuah PLTB dialiri angin dengan kecepatan angin $10 \mathrm{~m} /$ detik, maka $P_{W T e}(t)$ yang diproduksi pada PLTB XANT M-21 sebesar 83,1 kW, PLTB Electriawind Garbi sebesar 150 kW, PLTB XANT L-33 sebesar 250 kW, PLTB Enercon E40/5.40 sebesar 328 kW, PLTB Nordex N43-600 sebesar 363,63 kW, PLTB Vestas V47 sebesar 450 kW, PLTB Enercon E-48 sebesar 555 kW. Untuk menghitung nilai CF dalam setahun, maka dapat menggunakan Persamaan (5) (Ditkovich, dkk, 2012) (Gharibeh dkk, 2019).

$$
C F=\frac{\sum_{t=1}^{n} P_{W T e}(t)}{P_{r} \times n}
$$

Dengan, nilai $n$ dapat bernilai 12 jika perhitungan mengambil rerata dalam bulan, 365 jika perhitungan mengambil rerata perhari, dan 8.760 jika mengambil rerata dalam perjam. Untuk mendukung hasil perhitungan, maka kajian menggunakan perangkat lunak pendukung yaitu HOMER. Pada perangkat lunak HOMER data pembangkit PLTD, beban, potensi EBT dan PLT EBT dibutuhkan dalam proses analisis.

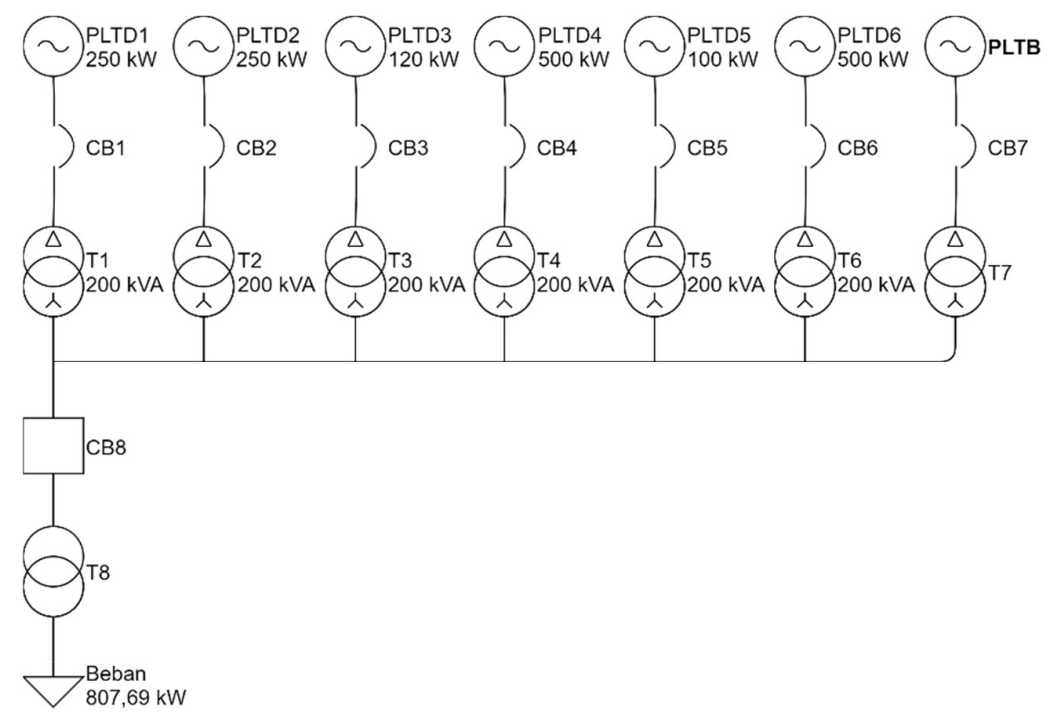

Gambar 6. Desain Skenario Sistem Mini-grid

Skenario sistem mini-grid hibrida dapat dilihat pada Gambar 6. Terdapat 3 komponen yaitu PLTD, PLTB, dan beban (Benevit, dkk, 2016). PLTD berfungsi sebagai pembangkit utama untuk mensuplai energi pada beban, sedangkan PLTB yang terpasang akan dikaji berdasarkan teknologi dan potensi tenaga angin yang dimiliki.

\subsubsection{Identifikasi Teknologi PLTB}

Tabel 2 merupakan daya keluaran pada teknologi PLTB komersial yang tersedia di pasaran yang dapat digunakan. Masing-masing teknologi memiliki daya keluaran $\left(P_{r}\right)$ yang dipengaruhi oleh rugi-rugi $\left(P_{\text {loss }}\right)$. Daya keluaran $\left(P_{r} \times P_{\text {loss }}\right)$ yang dihasilkan oleh PLTB lebih rendah dari daya rated-nya $\left(P_{r}\right)$ (Diyoke, 2019) (Menezes, dkk, 2020). Teknologi yang digunakan 
memiliki kapasitas daya $P_{r} 100 \mathrm{~kW}$ hingga $800 \mathrm{~kW}$. Hal tersebut dapat dijadikan pembanding teknologi dengan produksi energi yang optimum berdasarkan karakteristik kecepatan angin. Besar nilai $P_{r}$ tidak mempengaruhi energi yang diproduksi karena produksinya masih dipengaruhi oleh rugi daya, ketinggian tiang, dan distribusi Weibull kecepatan angin (Boccard, 2016) (Ditkovich \& Kuperman, 2014).

Tabel 2. Profil Daya Teknologi PLTB Komersial

\begin{tabular}{|c|l|c|c|c|}
\hline PLTB & \multicolumn{1}{|c|}{ Teknologi } & $\boldsymbol{P}_{\boldsymbol{r}}(\mathbf{k W})$ & $\boldsymbol{P}_{\text {loss }}$ & $\boldsymbol{P}_{\boldsymbol{r}} \times \boldsymbol{P}_{\text {loss }} \mathbf{( k W )}$ \\
\hline 1 & PLTB 1 - XANT M-21 & 100 & 0,13 & 87,0 \\
\hline 2 & PLTB 2 - Electriawind Garbi & 150 & 0,13 & 130,5 \\
\hline 3 & PLTB 3 - XANT L-33 & 330 & 0,13 & 287,1 \\
\hline 4 & PLTB 4 - Enercon E40/5.40 & 500 & 0,13 & 435,0 \\
\hline 5 & PLTB 5 - Nordex N43-600 & 600 & 0,13 & 522,0 \\
\hline 6 & PLTB 6 - Vestas V47 & 660 & 0,13 & 574,2 \\
\hline 7 & PLTB 7 - Enercon E-48 & 800 & 0,13 & 696,0 \\
\hline
\end{tabular}

Gambar 7 menunjukkan kurva daya pada masing-masing teknologi PLTB yang digunakan pada kajian. Grafik menunjukkan energi yang diproduksi pada titik $v_{\text {cut-in }}$, $v_{\text {rated }}$, dan $v_{\text {cut-out }}$. Setiap teknologi pembangkit mulai memproduksi energi pada titik $v_{c u t-i n}$ yang berbeda-beda. Hal ini mempengaruhi produksi $P_{r}$ pada titik $v_{\text {rated }}$ yang berbeda juga (Nemes \& Munteanu, 2011). Pada teknologi PLTB dengan $P_{r}$ di bawah $400 \mathrm{~kW}$ sama-sama berhenti menghasilkan daya pada titik $v_{\text {cut-out }}$ yang sama. Begitu juga pada teknologi PLTB pada antara $400 \mathrm{~kW}$ hingga 900 $\mathrm{kW}$ memiliki titik $v_{\text {cut-out }}$ yang sama.

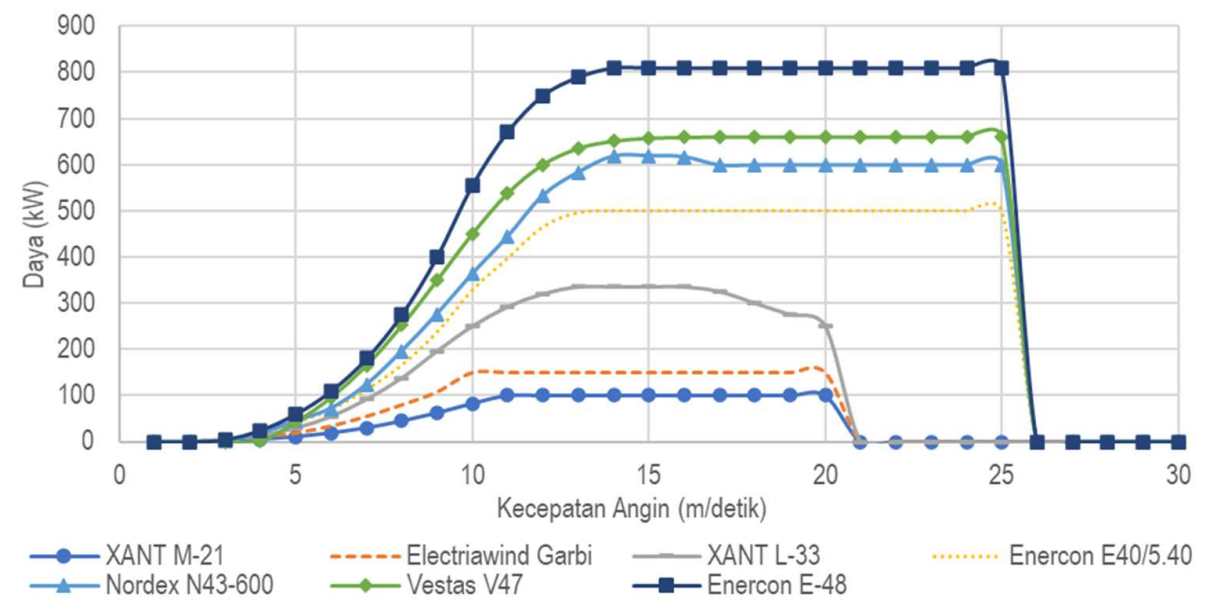

Gambar 7. Kurva Daya Berdasarkan Teknologi PLTB Komersial

Pada perhitungan dan simulasi, nilai daya yang dibangkitkan dan CF didapatkan berdasarkan ketinggian pemasangan PLTB. Untuk penelitian ini dipilih 4 skenario ketinggian yaitu $30 \mathrm{~m}, 40$ $\mathrm{m}, 50 \mathrm{~m}$ dan $60 \mathrm{~m}$ dari permukaan tanah. 


\section{HASIL DAN PEMBAHASAN}

\subsection{Distribusi Frekuensi Kecepatan Angin}

Distribusi frekuensi kecepatan angin dari kecepatan angin $1 \mathrm{~m} /$ detik sampai dengan $25 \mathrm{~m} /$ detik dalam setahun ditunjukkan pada Tabel 3. Total frekuensi dari kecepatan angin sebesar 8.760 yang merupakan jumlah jam dalam setahun.

\section{Tabel 3 Distribusi Frekuensi Kecepatan Angin di Elat, Maluku}

\begin{tabular}{|c|c|}
\hline $\boldsymbol{v}(\mathbf{m} /$ detik $)$ & Frekuensi \\
\hline 1 & 80 \\
\hline 2 & 223 \\
\hline 3 & 254 \\
\hline 4 & 336 \\
\hline 5 & 468 \\
\hline 6 & 580 \\
\hline 7 & 753 \\
\hline 8 & 911 \\
\hline 9 & 799 \\
\hline 10 & 769 \\
\hline 11 & 601 \\
\hline 12 & 700 \\
\hline 13 & 681 \\
\hline 14 & 493 \\
\hline 15 & 442 \\
\hline 16 & 279 \\
\hline 17 & 228 \\
\hline 18 & 108 \\
\hline 19 & 26 \\
\hline 20 & 14 \\
\hline 21 & 4 \\
\hline 22 & 5 \\
\hline 23 & 3 \\
\hline 24 & 1 \\
\hline 25 & 2 \\
\hline Total & $\mathbf{8 . 7 6 0}$ \\
\hline
\end{tabular}

\subsection{Hasil Perhitungan Daya PLTB Berdasarkan Kecepatan Angin}

Gambar 8 menunjukkan hasil keluaran $P_{W T e}$ berdasarkan kecepatan angin dan kurva daya PLTB yang dikalikan dengan jumlah frekuensi angin selama setahun. Tabel 4 menunjukkan hasil perhitungan total daya $\left(P_{T o t}\right)$, rerata daya yang dihasilkan per jam $\left(P_{W T}\right)$, dan daya rated $\left(P_{r}\right)$. 
Analisis Faktor Kapasitas Pembangkit Listrik Hibrida PLTB dengan PLTD di Pulau Terpencil: Studi Kasus Elat Pulau Serau Maluku

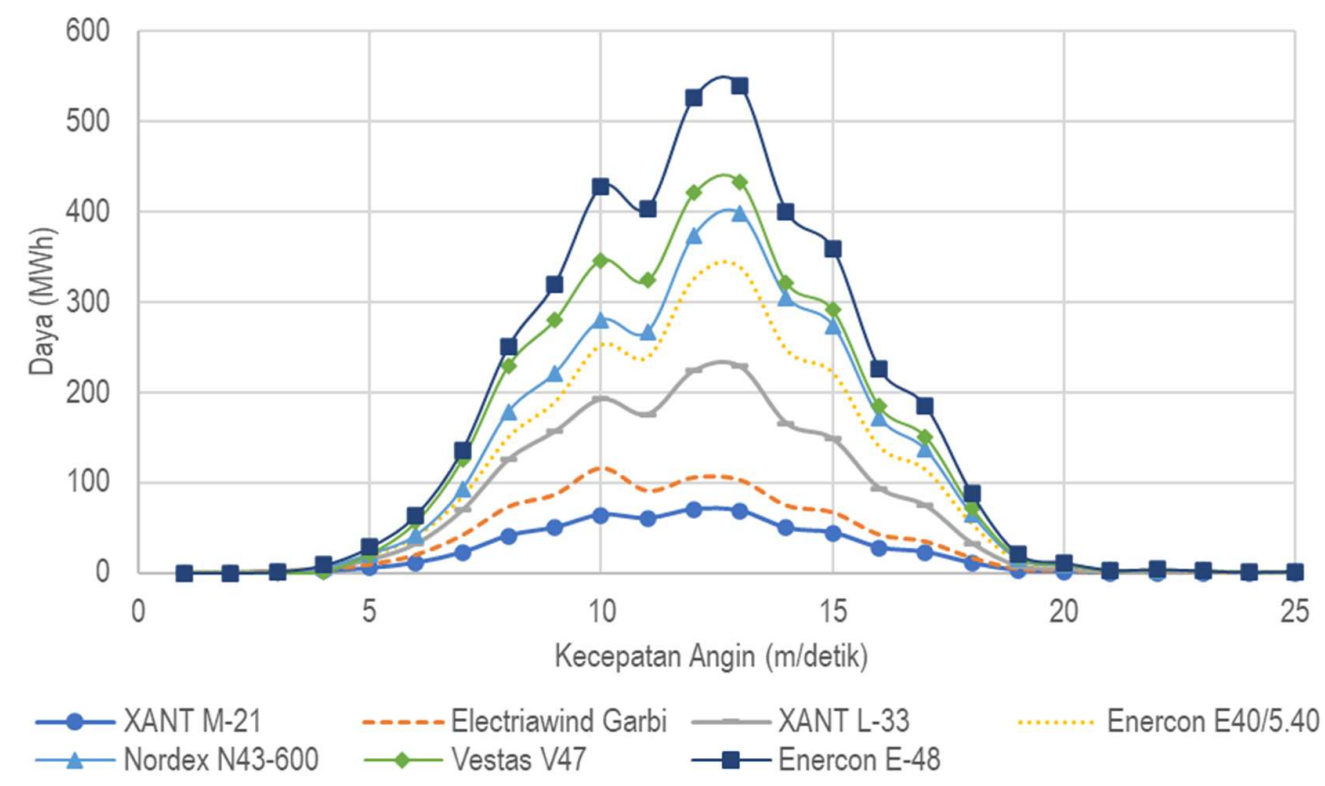

Gambar 8. Daya Keluaran PLTB Berdasarkan Frekuensi Kecepatan Angin

Tabel 4 Hasil Perhitungan Total Daya, Rerata Daya, dan Daya Rated

\begin{tabular}{|c|r|r|r|}
\hline PLTB & \multicolumn{1}{|c|}{$\begin{array}{c}P_{\text {Tot }} \\
\text { (kWh/tahun) }\end{array}$} & \multicolumn{1}{|c|}{$P_{W T}(\mathbf{k W})$} & \multicolumn{1}{|c|}{$P_{r}(\mathbf{k W})$} \\
\hline PLTB 1 & $18.086,02$ & 51,45 & 100 \\
\hline PLTB 2 & $22.052,11$ & 60,42 & 150 \\
\hline PLTB 3 & $38.725,15$ & 106,10 & 330 \\
\hline PLTB 4 & $49.035,63$ & 134,34 & 500 \\
\hline PLTB 5 & $55.637,21$ & 152,43 & 600 \\
\hline PLTB 6 & 68.954 .68 & 188,92 & 660 \\
\hline PLTB 7 & $81.051,70$ & 222,06 & 800 \\
\hline
\end{tabular}

Tabel 5 menunjukkan perbandingan $\mathrm{CF}$ hasil perhitungan $\left(C F_{W T}\right)$ dengan $\mathrm{CF}$ hasil simulasi $\left(C F_{\text {HOMER }}\right)$ PLTB 1 hingga PLTB 7 yang divariasi ketinggiannya dari $30 \mathrm{~m}, 40 \mathrm{~m}, 50 \mathrm{~m}$, dan 60 m. Hasil simulasi CF menggunakan perangkat lunak HOMER menunjukkan CF terbesar didapat sebesar 0,550 atau 55,0\%. Sedangkan dengan menggunakan metode perhitungan, nilai CF terbesar yang dihasilkan sebesar 0,549 atau 54,9\%. Nilai CF terbesar hasil simulasi dan perhitungan tersebut didapat pada ketinggian 50 m dengan menggunakan teknologi PLTB 2.

Relasi nilai CF (y) terhadap variasi ketinggian (x) dapat dinyatakan dalam fungsi linier dengan nilai gradien minimum 0,0017 (PLTB 4), gradien maksimum 0,004 (PLTB 2) dan gradien reratanya 0,0030 . Terlihat bahwa semakin tinggi tiang, nilai CF semakin besar sekitar 0,0030 kali tingginya. 
Wijaya, dkk

Tabel 5. Perbandingan CF per Ketinggian Tiang PLTB

\begin{tabular}{|c|c|c|c|c|c|}
\hline $\begin{array}{l}\text { Ketinggian } \\
\text { (m) }\end{array}$ & 30 & 40 & 50 & 60 & $\begin{array}{l}\text { CF (y) sebagai fungsi } \\
\text { ketinggian }(x)\end{array}$ \\
\hline \multicolumn{6}{|l|}{ PLTB 1} \\
\hline$C F_{W T}$ & 0,447 & 0,485 & 0,515 & & $y=0,0034 x+0,3463$ \\
\hline$C F_{\text {HOMER }}$ & 0,431 & 0,480 & 0,514 & & \\
\hline \multicolumn{6}{|l|}{ PLTB 2} \\
\hline$C F_{W T}$ & 0,478 & 0,518 & 0,550 & & $y=0,004 x+0,3537$ \\
\hline$C F_{\text {HOMER }}$ & 0,470 & 0,516 & 0,549 & & \\
\hline \multicolumn{6}{|l|}{ PLTB 3} \\
\hline$C F_{W T}$ & 0,427 & 0,463 & 0,491 & 0,514 & $y=0,0037 x+0,3025$ \\
\hline$C F_{\text {HOMER }}$ & 0,405 & 0,456 & 0,491 & 0,515 & \\
\hline \multicolumn{6}{|l|}{ PLTB 4} \\
\hline$C F_{W T}$ & 0,391 & 0,424 & 0,450 & 0,471 & $y=0,0017 x+0,3624$ \\
\hline$C F_{\text {HOMER }}$ & 0,412 & 0,434 & 0,451 & 0,464 & \\
\hline \multicolumn{6}{|l|}{ PLTB 5} \\
\hline$C F_{W T}$ & 0,380 & 0,413 & 0,438 & 0,458 & $y=0,0026 x+0,3057$ \\
\hline$C F_{\text {HOMER }}$ & 0,398 & 0,422 & 0,439 & 0,452 & \\
\hline \multicolumn{6}{|l|}{ PLTB 6} \\
\hline$C F_{W T}$ & 0,398 & 0,432 & 0,458 & 0,479 & $y=0,0027 x+0,3207$ \\
\hline$C F_{\text {HOMER }}$ & 0,371 & 0,423 & 0,460 & 0,487 & \\
\hline \multicolumn{6}{|l|}{ PLTB 7} \\
\hline$C F_{W T}$ & 0,400 & 0,433 & 0,460 & 0,490 & $y=0,003 x+0,3121$ \\
\hline$C F_{\text {HOMER }}$ & 0,422 & 0,444 & 0,461 & 0,480 & \\
\hline
\end{tabular}

\subsection{Perhitungan Galat Hasil Simulasi}

Tabel 6 menunjukkan data rerata CF dari hasil perhitungan dan CF dari simulasi HOMER. Untuk analisis dengan ketinggian tiang PLTB 30 m, data CF PLTB Elat memiliki rerata galat untuk setiap teknologi sebesar $-0,49 \%$, sedangkan data CF PLTB Elat memiliki rerata galat untuk setiap teknologi sebesar $-1,82 \%$. Rerata tersebut lebih besar dibanding rerata CF PLTB Elat. Untuk analisis dengan ketinggian tiang PLTB $40 \mathrm{~m}$, data CF PLTB Elat memiliki rerata galatuntuk setiap teknologi sebesar 0,24\%, sedangkan data CF PLTB Elat memiliki rerata galatuntuk setiap teknologi sebesar $-1,12 \%$. Rerata tersebut lebih besar dibanding rerata CF PLTB Elat. Untuk analisis dengan ketinggian tiang PLTB $50 \mathrm{~m}$, data CF PLTB Elat memiliki rerata galat untuk setiap teknologi sebesar $0,16 \%$, sedangkan data CF PLTB Elat memiliki rerata galat untuk setiap teknologi sebesar $-0,60 \%$. Rerata tersebut lebih besar dibanding rerata CF PLTB Elat.

Tabel 6. Perbandingan Rerata CF PLTB di Elat

\begin{tabular}{|l|l|l|l|l|}
\hline Ketinggian (meter) & 30 & 40 & 50 & Rerata \\
\hline Rerata Galat(\%) & $-0,489$ & 0,244 & 0,155 & $-0,030$ \\
\hline
\end{tabular}

Saat semua galat hasil perhitungan direratakan, maka didapat rerata setiap hasil perhitungan dan simulasi CF PLTB. Untuk wilayah Elat, memiliki rerata galat hasil perhitungan sebesar $-0,03 \%$. Untuk analisis data kecepatan angin di Elat menggunakan sampling data per jam setiap tahunnya, memiliki galat perhitungan yang lebih kecil. 
Analisis Faktor Kapasitas Pembangkit Listrik Hibrida PLTB dengan PLTD di Pulau Terpencil: Studi Kasus Elat Pulau Serau Maluku

\subsection{Analisis Konsumsi Energi Listrik}

Tabel 7 menunjukkan perbandingan konsumsi energi PLTD saat PLTB terhubung dalam grid. Analisis tersebut dilakukan pada ketinggian $50 \mathrm{~m}$ dengan menggunakan perangkat lunak HOMER.

Tabel 7. Perbandingan Rerata CF PLTB di Elat

\begin{tabular}{|c|c|c|c|c|c|c|c|}
\hline & PLTB 1 & PLTB 2 & PLTB 3 & PLTB 4 & PLTB 5 & PLTB 6 & PLTB 7 \\
\hline $\begin{array}{l}\text { Daya PLTB } \\
\text { (kW) }\end{array}$ & 100 & 150 & 330 & 500 & 600 & 660 & 800 \\
\hline Jumlah & 5 & 3 & 2 & 1 & 1 & 1 & 1 \\
\hline $\begin{array}{l}\text { Total Daya } \\
\text { PLTB (kW) }\end{array}$ & 500 & 450 & 660 & 500 & 600 & 660 & 800 \\
\hline CF (\%) & 51,4 & 55,0 & 50,7 & 45,1 & 43,9 & 46,0 & 48,0 \\
\hline $\begin{array}{l}\text { Total Energi } \\
\text { PLTB } \\
\text { Setahun } \\
\text { (kWh) }\end{array}$ & 2.703 .035 & 2.890 .484 & 2.933 .359 & 1.976 .349 & 2.306 .398 & 2.657 .161 & 3.364 .265 \\
\hline $\begin{array}{l}\text { Total Energi } \\
\text { PLTD } \\
\text { Setahun } \\
\text { (kWh) }\end{array}$ & 2.932.989 & 2.745 .540 & 2.702 .665 & 3.659 .675 & 3.329 .626 & 2.978 .863 & 2.271 .759 \\
\hline $\begin{array}{l}\text { Konsumsi } \\
\text { Bahan Bakar } \\
\text { (L/tahun) }\end{array}$ & 916.823 & 877.430 & 883.907 & 1.056 .640 & 1.000 .656 & 935.992 & 851.980 \\
\hline $\begin{array}{l}\text { Kontribusi } \\
\text { Penurunan } \\
\text { Daya } \\
(\%) \\
\end{array}$ & 47,96 & 51,29 & 52,05 & 35,07 & 40,92 & 47,15 & 59,69 \\
\hline $\begin{array}{l}\text { Kontribusi } \\
\text { Pengurangan } \\
\text { Bahan Bakar } \\
(\%)\end{array}$ & 39,37 & 41,98 & 41,55 & 30,13 & 33,83 & 38,11 & 43,66 \\
\hline
\end{tabular}

Beberapa parameter yang diamati yaitu daya pada masing-masing PLTB, jumlah PLTB yang dimasukkan dalam grid, nilai CF saat ketinggian $50 \mathrm{~m}$, total daya yang dihasilkan masingmasing PLTB dalam setahun, total daya beban dalam setahun, total daya yang dihasilkan PLTD dalam setahun, dan penginjeksian daya PLTD sebagai cadangan untuk mensuplai kebutuhan energi listrik. Nilai injeksi daya PLTD, menunjukkan selisih antara beban dalam setahun dengan total energi PLTB dalam setahun. Saat terjadi kekurangan daya, PLTD mensuplai sesuai dengan kebutuhan beban. Jika daya yang dihasilkan oleh PLTB lebih besar, maka PLTD menginjeksikan daya ke beban lebih sedikit.

Besarnya daya yang dihasilkan oleh PLTB, menyebabkan PLTD memproduksi energi lebih rendah. Hal tersebut dapat dilihat pada hasil analisis PLTB 2, 3, dan 7. Pada analisis PLTB 7 menunjukkan energi yang diproduksi lebih besar. Dimana pada PLTB 7, energi yang dihasilkan sebesar 3.364.265 kWh, sehingga mampu menekan produksi listrik pada PLTD sebesar 59,69\%. Besarnya kontribusi PLTB 7 dalam penurunan energi listrik pada PLTD membuat penurunan konsumsi bahan bakar hingga 851.980 liter/tahun atau sebesar 43,66\%. Energi terendah dihasilkan pada PLTB 4 sebesar $1.976 .349 \mathrm{kWh}$.

Besarnya nilai CF tidak menentukan besar kontribusi PLTB dalam memenuhi kebutuhan beban. Hal tersebut dikarenakan terdapat waktu dimana PLTB mampu menghasilkan energi listrik lebih besar, tetapi kebutuhan listrik pada beban sangat kecil. Saat PLTB beroperasi dengan 
profil beban pada Gambar 3 dan potensi kecepatan angin pada Gambar 4, terdapat energi listrik yang terbuang. Pada PLTB 1 dan 7 menunjukkan perbandingan yang sangat terlihat. Nilai CF pada PLTB 1 sebesar 51,4\% sedangkan nilai CF pada PLTB 7 sebesar 48,0\%. Perbandingan nilai CF pada PLTB 1 lebih besar dibandingkan PLTB 7. Akan tetapi produksi listrik yang dihasilkan pada PLTB 1 sebesar 2.703.035 kWh sedangkan produksi listrik pada PLTB 7 sebesar 3.364.265 kWh. Hal tersebut menunjukkan produksi listrik pada PLTB 7 lebih besar daripada PLTB 1. Besarnya daya pada PLTB 7 sebesar 800 kW dan daya pada PLTB 1 sebesar 600 kW. Perbedaan teknologi dapat mempengaruhi besar produksi energi listrik.

\section{KESIMPULAN}

Dari penelitian ini telah dapat diperoleh hasil perhitungan faktor kapasitas (CF) PLTB di Elat untuk 5 tipe teknologi PLTB. Hasil perhitungan telah diverifikasi dengan menggunakan perangkat lunak HOMER dengan nilai rerata galat-0,030. Semakin tinggi tiang nilai CF PLTB semakin besar dengan konstanta 0,0030 kali tingginya. Hal tersebut dikarenakan semakin tinggi tiang PLTB, kecepatan angin semakin besar. Untuk sistem hibrida PLTB dengan PLTD, pemanfaatan energi angin dapat mengurangi energi listrik yang harus disediakan oleh PLTD. Pada PLTB 7 mampu menghasilkan energi listrik sebesar 3.364.265 kWh sehingga mampu mengurangi konsumsi bahan bakar sebesar 851.980 liter/tahun atau menekan konsumsi bahan bakar PLTD hingga 43,66 \%.

\section{UCAPAN TERIMA KASIH}

Terima kasih penulis ucapkan kepada PT. PLN PUSLENLIS yang telah memberikan bantuan berupa data-data teknis yang dibutuhkan dalam penelitian ini.

\section{DAFTAR RUJUKAN}

Al-Quraan, A., \& Alrawashdeh, H. (2018). Correlated Capacity Factor Strategy for Yield Maximization of Wind Turbine Energy. 5th International Conference on Renewable Energy: Generation and Application, (pp. 264-267).

Andrea, A.E., Miguel F., Eisman J., et.al. (2019). Lessons Learned from Rural Electrification Experiences with Third Generation Solar Home Systems in Latin America: Case Studies in Peru, Mexico, and Bolivia. Sustainability Journal, 11(12), 1-24.

Benevit, M. G., Silva, J. S., Gewehr, A. G., \& Beluco, A. (2016). Subtle Influence of the Weibull Shape Parameter on Homer Optimization Space of a Wind Diesel Hybrid Gen Set for Use in Southern Brazil. Journal of Power and Energy Engineering, 4(8), 38-48.

Boccard, N. (2009). Capacity Factor of Wind Power: Realized Values vs. Estimates. SSRN Energy Policy, $37(7), 2679-2688$.

Bokde, N. (2018). Wind Turbine Power Curves Based on the Weibull Cumulative Distribution Function, Applied Sciences, 8(9), 1-18.

Chang, T., Liu, F., Ko, H., Cheng, S., \& Sun, L. (2014). Comparative analysis on power curve 
Analisis Faktor Kapasitas Pembangkit Listrik Hibrida PLTB dengan PLTD di Pulau Terpencil: Studi Kasus Elat Pulau Serau Maluku

models of wind turbine generator in estimating capacity factor. Energy, 73 (7), 88-95.

Direktorat Jenderal Ketenagalistrikan. (2019). RUPTL PLN 2019-2028. Retrieved from https://gatrik.esdm.go.id.

Ditkovich, Y., \& Kuperman, A. (2014). Comparison of Three Methods for Wind Turbine Capacity Factor Estimation. The Scientific World Journal, 2014(1), 1-7.

Ditkovich, Y., Kuperman, A., Yahalom, A., \& Byalsky, M. (2012). A generalized approach to estimating capacity factor of fixed speed wind turbines. IEEE Transactions on Sustainable Energy, 3(3), 607-608.

Diyoke, C. (2019). A New Approximate Capacity Factor Method for Matching Wind Turbines to a Site:Case Study of Humber Region, UK. International Journal of Energy and Environmental Engineering, 10(4), 451-462.

Gharibeh, H. F., Khiavi, L. M., Farrokhifar, M., Alahyari, A., \& Pozo, D. (2019). Capacity value of variable-speed wind turbines. IEEE Milan PowerTech, (pp 1-5).

EBTKE. (2019). Kerja Sama Strategis RI-Jerman: Majukan Energi Terbarukan dengan Pelibatan Swasta. Retrieved from http://ebtke.esdm.go.id.

Kementerian Energi Dan Sumber Daya Mineral Republik Indonesia. (2019). Wujudkan 100\% Rasio Elektrifikasi, Kementerian ESDM akan Manfaatkan Tabung Listrik. Retrieved from https://www.esdm.go.id.

Menezes, D., Mendes, M., Almeida, J. A., \& Farinha, T. (2020). Wind Farm and Resource Datasets: A Comprehensive Survey and Overview. Energies, 13(18), 1-24.

Nemes, C., \& Munteanu, F. (2011). The Wind Energy System Performance Overview: Capacity Factor vs Technical Efficiency. International Journal of Mathematical Models and Methods in Applied Sciences, 5(1), 159-166.

Plugia, G., Moroni , M. , Fagnani, M., Comodi, G. (2017). A design approach of off-grid hybrid electric microgrids inisolated villages: a case study in Uganda. The 8th International Conference on Applied Energy, (pp. 3089 - 3094).

PwC global power \& utilities (2016). Electricity beyond the grid: Accelerating access to sustainable power for all. https://www.pwc.com/gx/en/energy-utilitiesmining/pdf/electricity-beyond-grid.pdf

Sambodo T.S. (2015). Rural Electrification Program in Indonesia: Comparing SEHEN and SHS Program. Economics and Finance in Indonesia 61(2), 107-119.

Song, D., Yang, Y., Zheng, S., Tang, W., Yang, J., Su, M., Yang, X., \& Joo, Y. H. (2019). Capacity factor estimation of variable-speed wind turbines considering the coupled influence of the QN-curve and the air density. Energy, 183(9), 1049-1060. 
Subhes C. Bhattacharyya, Debajit, P. (2016). Mini-grid based off-grid electrification to enhance electricity access in developing countries: What policies may be required?, Energy Policy 94(6), 166-178.

Walia, S., \& Sandhu, K. S. (2019). Capacity factor of wind turbine system based on different power curves and Weibull distribution parameters. The 3rd International Conference on Computing Methodologies and Communication, (pp. 1135-1138).

Worldometer. (2020). Current World Population. Retrieved from https://www.worldometers.info/world-population/ 